\title{
ORGANIZATION OF RURAL MICROBUSINESSES UNDER SPECIFIC FAMILY OWNERS CONDITIONS
}

\author{
Maylis Sposito ${ }^{1}$
}

Received 23 January 2015; Accepted 7 September 2015

\begin{abstract}
The Interreg IV-A research project aims at analysing the socioeconomic consequences of disruptive situations in microbusinesses of the rural French-Swiss Jura region. Several researchers are focusing on this topic within the various institutions involved in the project ${ }^{2}$. I will rather focus on the common characteristics of microbusinesses on either side of the border. These similarities pertain to the overlapping of the family and business spheres, which often involves an overlapping of statuses, and to the gender relations induced by this overlapping, as well as to the precarious economic situation of these small structures. This article aims at putting into perspective the typology originated by all the biographical interviews collected. This typology compares the figure of the family business heir to that of the self-taught entrepreneur. Such a difference in achieving professional independence brings about strategic patterns of separation/fusion between private and professional lives, patterns which are specific to each above-mentioned ideal type. This typology is yet to be refined, but it already draws attention to the strategies developed by players to separate - or not - family and business spheres. Thus, by tackling the issue of disruption through this typology of company managers, the article will show various influential elements in the event of a disruption, both on the viability of the company and on the personal itinerary of the people involved.
\end{abstract}

Keywords: Microbusinesses, Disruptions, Rural development, Family business, FranceSwitzerland comparison, Creator-Heir, Jura region.

Résumé: Le projet de recherche Interreg IV-A a pour objectif d'analyser les conséquences socio-économiques des situations de rupture de trajectoire dans les Très Petites Entreprises rurales de l'Arc jurassien franco-suisse. Plusieurs chercheur.e.s sont réunis autour de cette recherche en fonction des différentes institutions engagées dans le projet $^{3}$. J'axerai davantage sur les caractéristiques communes des TPE de chaque côté de la frontière. Ces caractéristiques communes relèvent d'une superposition des sphères familiale et professionnelle entrainant souvent une superposition des statuts, des rapports de genre au travail que cette superposition induit, ainsi que les situations économiques fragiles dans ces petites structures. Cet

\footnotetext{
1 Maylis SPOSITO: Research engineer and Interreg IV-A project coordinator, as well as Ph.D. Candidate at the University of Franche-Comté Sociology and Anthropology Laboratory, 30 rue Mégevand, 25030 Besançon Cedex, France; maylis.sposito@edu.univ-fcomte.fr.

2 University of Franche-Comté Sociology and Anthropology Laboratory and The Graduate Institute of Geneva.

${ }^{3}$ Le laboratoire de Sociologie et d'Anthropologie de I'Université de Franche-Comté et l'Institut de Hautes Etudes Internationales et du Développement.
} 
article se propose donc de mettre en perspective la typologie élaborée à la suite des entretiens biographiques réalisés. Cette typologie met en regard la figure de l'héritier de l'entreprise familiale avec celle du créateur autodidacte. De cette différence de mode d'accès à l'indépendance professionnelle découle un apanage stratégique de séparation/fusion privé-professionnel différent entre les deux idéaux-type énoncées précédemment. Cette typologie sera davantage affinée mais elle permet de mettre en exergue les stratégies développées par les acteurs pour séparer ou non la sphère familiale de la sphère professionnelle. Ainsi, en abordant la problématique de la rupture par le biais de cette typologie des chef.fe.s d'entreprise, cet article montrera les divers éléments infléchissant en cas de rupture aussi bien sur la viabilité de l'entreprise que sur la destinée des individus.

Mots-clés: Très Petites Entreprises, Ruptures, Développement rural, Entreprise familiale, Comparaison France-Suisse, Créateur-Héritier, Arc Jurassien.

\section{Introduction}

The Interreg IV-A research project aims at analysing the socio-economic issues of disruptive situations in rural French-Swiss Jura region microbusinesses. To understand causes and consequences of biographical disruptions on business, its director and relatives, this research favors a qualitative method with interviews. Data in this article come from empirical materials collected by inductive way. The aim of this research-action is to maintain the economic networking regarding the importance of microbusinesses in this region ${ }^{4}$. Indeed, a familial disruption can affect and weaken the enterprise even lead to bankruptcy. Businesses - more precisely their sizes - are the converging elements between craftsperson, storekeeper, farmer and industrialist. When choosing the size of companies instead of a particular occupational sector, such as handicraft (Zarca, 1986) or trade (Gresles, 1981), we are faced to many eclectic situations. But we would like to approach the business as an economic, legal, familial and patrimonial entity. In this paper I would like to question what the family does to the company and conversely. The microbusinesses imply frequently an important overlapping between private sphere and professional sphere, between family and business. This is why this paper intends to underline different involvements of family in the enterprise according to our typology. The different investment of the family circle according to inheritance of the business by the director or a creation of the enterprise underpins consequences more or less important in a disruption. Thus, analysing the self-employed work correlated to the family, I will underline the separation through an empirical typology between creators and heirs. These two groups of company managers do not refer to the same professional justification and do not use the same management strategies about the family-owned company. First of all, I will clarify the defining elements of the Interreg research project along with the territory under study. Secondly, I will show how family has an effect on the company right from the beginning. Afterwards, I will revisit the typology of heirs and creators in defining their distinctive features. Finally, I will explain the different strategies introduced by company managers to ensure business durability.

\section{Definition of the elements pertaining to the research topic}

First of all, I will of course revisit more precisely the defining elements of the research project, especially as regards the territory under study, the way to characterise what is rural or not and explain why microbusinesses are vectors of economic dynamism in rural areas.

\section{a. The area under study: the Jura French-Swiss region}

The Jura French-Swiss region is a cross-border territory in which there is some cooperation. These links underline historical cooperation continuity between France and Switzerland. The ongoing research focuses on this geographic area with delimited frontiers. More precisely,

\footnotetext{
${ }^{4} 90.5 \%$ of businesses in this region are microbusinesses.
} 
it includes four departments of the Franche-Comté region - Doubs, Jura, Haute-Saône and Territoire de Belfort - and four Swiss cantons - Vaud, Jura, Neuchâtel and Bernese Jura.

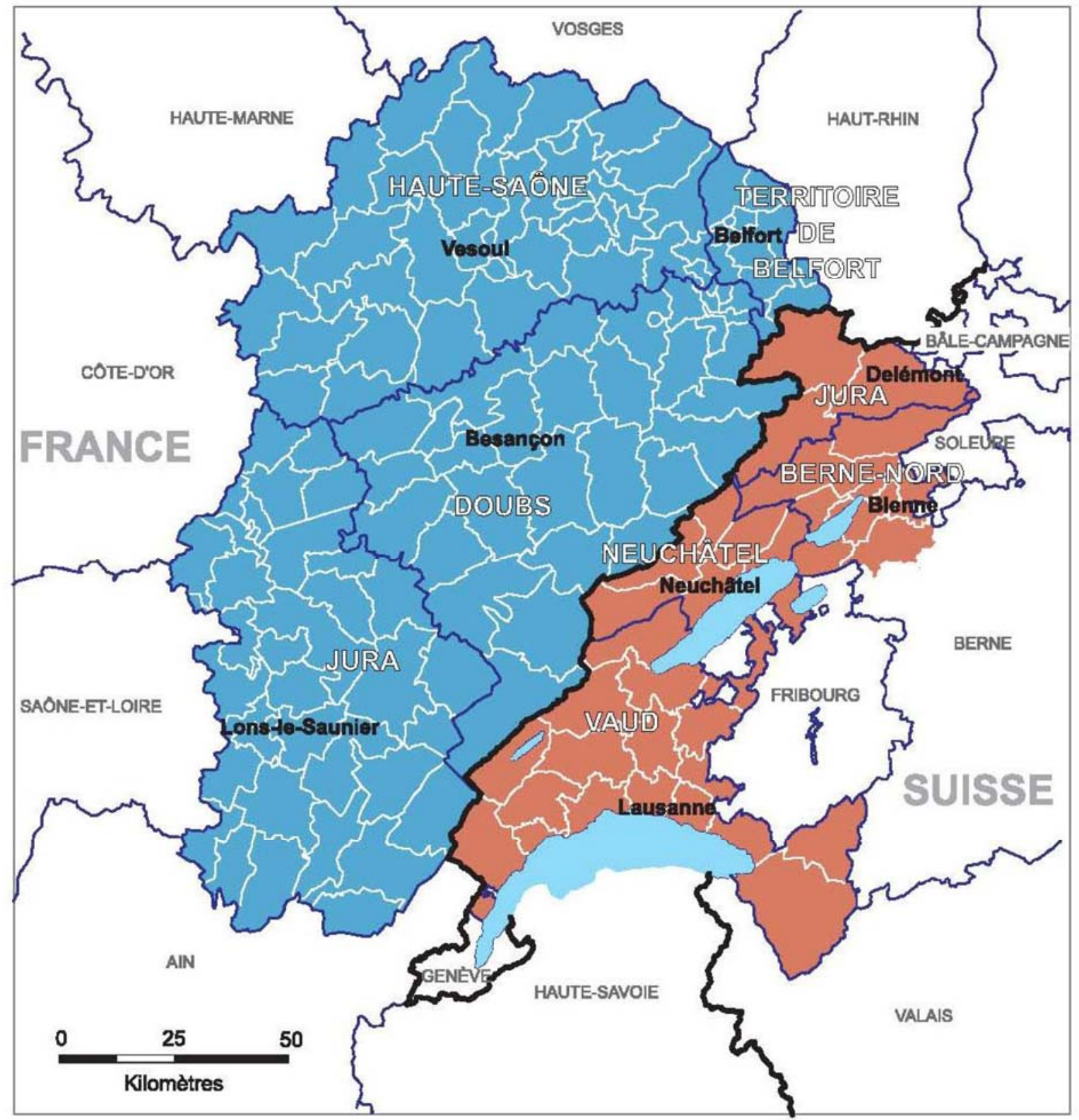

Fig 1. Illustrated map of the French-Swiss Jura Region, Observatoire Statistique Transfrontalier de l'Arc Jurassien.

The French-Swiss Jura area is a border territory whose economic dynamism was given a boost by clock-making and daily workers passing through between the two countries. Common history of both states now leads to a migration movement of persons of expertise in the booming sector of micro-technology. This territory constitutes an important employment basin for European members. Besides the flow of workers between the two countries, some researchers talk about a shapeless but complementary space (Moine, 2003) regarding the economic and cultural dynamism encouraged by clock-making. The common history between both creates a fertile ground for an international comparison. 


\section{b. A mostly rural territory}

Proportionally, the Swiss part is more populated than the French one. In 2006, the population density was 71.5 inhabitants $/ \mathrm{km}^{2}$ in France and 207.1 inhabitants $/ \mathrm{km}^{2}$ in Switzerland ${ }^{5}$. FrancheComté is an industrial region, the first in France for some categories of employment (Daumas, 2012). But Franche-Comté remains a region where rural areas are predominant and structured around three urban hubs: Montbéliard, Belfort and Besançon. A binary taxonomy between urban and rural shows that, in Franche-Comté, $89 \%$ of municipalities are considered rural 6 . Nevertheless, we did not choose this dimidiation strictly based on quantitative data, i.e. the number of inhabitants per municipality. Such dichotomy does not take into account the different scales between cities, areas around cities, isolated towns and rural areas. If we take into account these variables, the Franche-Comté region can be subdivided into 11 urban areas, gathering 957 urban municipalities and towns around cities ${ }^{7}$. According to the French National Institute for Statistics and Economic Researches definition, urban area is a geographical boundary which brings municipalities together (rural and towns around cities). These towns are around urban centre with more than 10000 employments. This dividing is interesting because it enables us to distinguish centre where are gathered habitat and employment and other municipalities under centre influence concerning home-job travels. Rural areas are defined in accordance with distance with urban centre where are employments and infrastructures. The rest of the territory includes 829 municipalities which constitute the rural areas $^{8}$. As for the Swiss territory, the same distinction is drawn by the Federal Statistical Office between "urban regions" and "rural region". This classification ${ }^{10}$ is enough to identify the territories where there are microbusinesses concerned by the Interreg project. However, I must point out that geographers have developed other analysis scales to comprehend territories $^{11}$, but these details cannot be used within the 2-year time frame of this research study. According to these demographical and geographical data, I would like to underline the rural areas extent in this French-Swiss region. In this sense, we may assume that microbusinesses in rural areas - flourishing local shops and services interlocked in acquaintanceship networks correlated to the employment distance - are constitutive elements of economic and social dynamism in rural areas.

\section{c. Predominance of microbusinesses in the research area}

Let me return to microbusinesses' characteristics in the French-Swiss Jura Territory. According to the European Committee in 2003, microbusiness is a company with fewer than 10 employees whose turnover does not exceed 2 million euros. This kind of establishment represents $90.5 \%$ of all establishments in the area ${ }^{12}$. So it's noteworthy that microbusinesses are abundant on the French-Swiss territory, and contribute to the economic dynamism of the border region. Thus, it seems interesting to understand both causes and consequences of disruptive situations in microbusinesses in rural areas. Nevertheless, this paper is not limited to this sole dimension. I would like to endeavour to expound the familial and professional structure of microbusinesses.

\footnotetext{
${ }^{5}$ OSTAJ, « Portraits de territoires ».

6 INSEE, « Unités urbaines $2010 »$.

7 In Franche-Comté, 92 municipalities are strictly urban and gathered, in 1999, 43\% of the region's population on $5.3 \%$ of the territory, INSEE.

${ }^{8}$ Ministère de l'Agriculture et de la Pêche, « Document régional de développement rural - Franche-Comté. 20072013».

${ }^{9}$ We refer here to the basic typology used by the OFS as part of population censuses. All the collected data can be accessed on the OFS website. See also the OFS report (2005) on geographical levels in Switzerland.

${ }^{10}$ Which is similar between the Federal Statistical Office and the French National Institute for Statistics and Economic Researches.

11 Indeed, geographers have developed many typologies to characterise municipalities and territories: urban areas, predominantly urban areas, utilised agricultural lands, rural development zones, enlarged urban areas, major urban centres, peripheral rings, industrial and urban population areas, employment areas, living areas, economic reorganisation areas, etc.. Some typologies can be quite detailed.

12 93\% in Franche-Comté departments and 87\% for the Swiss region, OSTAJ, "Portrait de territoire", 2007.
} 


\section{d. The type of disruption considered}

As part of this research study, we undertake to analyse the ability of microbusinesses to face biographical disruptions. What we refer to as "biographical disruptions" are the events affecting members of the family, either temporarily or on a long-term basis. These changes lead to a reorientation or a complete rethink of future plans. More precisely, we aspire to understand the causes and consequences of chronic or incapacitating illness, disabling accidents, premature deaths by accident, illness or suicide, major arguments and disagreements that may drive people to break off all ties - either between ancestors and descendants, between siblings, or in the case of a marital break-up or a divorce. All these disruptive events affecting one of the members of the family who works as a professional within the company bring about an arbitration that may spark a conflict as regards the economic and patrimonial situation of the company. So we are facing heterogeneous situations which must be considered both as potential causes of bankruptcy and as the consequences of tensions between individuals living and working together on a long-term basis.

\section{Methodology and sampling}

As I said previously, we favour an inductive method for the data collection. We had to make 60 life story interviews on each side of the border to understand the players' representations about family, labour and their roles in the company. The interview deals with the emergence of the company - either inheritance or creation; labour organization - gendered division of labour, status and role in the company between members of the family circle; the manager's choices for protection of the business or the family - business legal status, wedding arrangements for spouses etc.; the economic situation of the company; the issue of family handover and the real or predictable consequences of a disruptive situation in the company.

We chose to define the sampling progressively to cover the whole gamut of situations. So we interviewed male and female managers or spouses in every French department and Swiss canton; companies with different legal statuses - limited liability company or sole proprietorship - in different occupational sectors - agriculture, handicraft, service provision etc.; and finally, people who have experienced a family break-up, to analyse its consequences on family and business, and others who have not experienced it, to find out where they stand about it.

The first analytical threads in this article are based on 20 biographical interviews with company managers or their spouses in a rural environment ${ }^{13}$. All these life stories have been collected in the French-Swiss Jura region, namely via 5 interviews in Switzerland and 15 in France ${ }^{14}$. Among the companies, 8 worked in the agricultural sector, 3 in trade, 3 in services, 1 in industry and 5 in handicraft. I chose to deal with heterogeneous cases - as regards status, professional group, gender, business sector - so as to get a wide range of situations, representative of all potentialities. For the interviews, spouses were frequently there and spoke with us. To interview directors male and female or their spouses implies that we access to the confrontation of point of views and representations regarding everyday life management and importance of the enterprise and work. It is true that spouses did not present during every interviews, nevertheless when they were there, their speech had enhanced analysis. The aim of the research is to understand reasons and results of disruptive situations on the business, the manager and his relatives. So it was essential to access to actors social representations and to multiply the opinions to understand disruptions.

\section{Results and discussion}

\section{a. Overlap of family and work: couple in charge of the company}

Preliminary knowledge about this territory and the exploratory inquiry allow us to say that family microbusinesses face the same problems during a disruptive situation - for instance,

\footnotetext{
13 "Rural environment" in the sense previously defined.

14 On the French side: 6 in Jura, 6 in Doubs and 3 in Haute-Saône departments. On the Swiss side: 2 in the canton of Vaud, 1 in Jura and 2 in Bernese Jura.
} 
overlapping between family and company, undefined professional status for family members who work in the company - especially for wives, a gendered division of labour, emotional ties, that are more important when the company was inherited than when it was created etc.. What we intend to do here is to put into sharper perspective the family ties that make microbusinesses such specific economic entities. Microbusinesses do not necessarily function according to the liberal economic dynamics conceptualised by classic economists, they also rely on solidarity principles that contribute to make them competitive on the market (Zalio, 1999). A business, in the neoliberal sense of the word, is often considered to be an economic entity which produces wealth. Nevertheless, even though the familial dimension of businesses is not really taken into account by the institutions presiding over self-employment, the topic has been the subject of much scrutiny in social sciences for quite a long time, regarding small and medium size businesses or multinational corporations alike (Daumas, 2010; Pinçon et PinçonCharlot, 2006). Jean-Claude Daumas defines family business as a company in which capital ownership belongs for the most part to the family, the business is managed by the family, and the transmission to the next generation is a real concern for the manager (Daumas, 2010, p. 829). To characterise microbusinesses more specifically, we must add another element to this definition, namely the actual work done by family members within the company, be it sporadically or regularly. Indeed, almost three quarters of the businesspeople in our study work with their spouses or with at least one member of their expanded family on a daily basis, and the sporadic help of any other relative is not taken into account.

The overlap of family and business depends to a great extent on the company's business sector. It is most obvious in the catering, bakery, butchery and agriculture industry, which may be defined as activities for couples. Yet, the familial organisation of work, either within a couple or within an intergenerational or intra-generational association, is generally based on a gendered division of work. Setting up an independent business seems to be a decision frequently taken by both spouses, as it is perceived as a long-term project, likely to be considered by some people as a form of intergenerational social mobility, ipso facto involving other members of the family as well. The setting-up project materialises as a result of a decision taken beforehand by the couple. Such decision-making is correlated to the various configurations to which professional independence can lead, especially in microbusinesses (Bertaux-Wiame, 2004). Indeed, the wife ${ }^{15}$ may well work for the company, with or without a status, and without a clearly defined position, as her work is often based on her flexibility and her capacity to adjust to various jobs if need be. The wife may also be in charge of the household, without having a job within or without the family business, but therefore compensating for organisational difficulties. In these two situations, the wives' work is characterised by a major gendered division of tasks - they are often in charge of the administrative tasks and accounts of the business, and when the couple's activity requires the presence of two people, as in a butcher's shop or a bakery, they attend to customers.

However the wife may also be employed outside the family business, thus enabling the company manager to add her salary to the business income and compensate for potential economic difficulties. Moreover, the wife's salaried activity is also a welcome contribution when a couple is planning to create a microbusiness. It should be noted that those three forms of marital-professional organisations - either the wife working for the company, the wife taking care of the domestic and educational sphere without practising a profession within or without the company, and the wife working outside the family business - have been encountered in the interviews conducted for the research study.

The overlap of the productive and reproductive dimensions also brings about an overlap of social statuses. When considering the most widespread organisational pattern, we come across situations where the father is also the company manager, the mother is often a co-worker and the son, a potential successor (Jacques-Jouvenot, 1997). This undifferentiation of roles has an impact on everyone's status within the company. So it is quite common for the wife to "give

15 The rate of business creation or take-over by women is 30\% in France (INSEE, SINE, 2006) and $25 \%$ in Switzerland (Kyora, 2003). Therefore, I will focus on the role and the position of the manager's wife to illustrate the most frequent mode of operation of professionally independent couples. 
a helping hand"16 for free, as part of a gift economy. Within this framework, "the marriage contract serves as an employment contract" (Bertaux-Wiame, 2004, p. 15). Beyond the mere overlap of the familial and professional spheres, the particularity of self-employment often involves a mutual agreement, prior to the creation of the business. Therefore what François Gresle drew attention to in the early 1980s, namely the fact that forming a couple or getting married often preceded the setting-up of an independent business, still seems to be relevant today in the biographical narratives of the entrepreneurs we met for the research study. Indeed, out of the 20 interviews analysed, only a single subject had become a self-employed worker after going through a dismissal and a divorce. So it seemed pertinent to highlight the issues pertaining to the marital sphere in microbusinesses, since this type of company implies "almost necessarily the active presence of a family to surround, guide and support the independent worker" (Gresle, 1981, p. 487).

\section{b. The working couple against economic frailty}

One common feature about the people we interviewed is that they all run companies with limited funds for their projected accounting capacities and a precarious treasury that cannot easily cope with late payments. This economic tension is tangible throughout the interviews, especially for couples who have no employees and whose business and household accounts are more or less intertwined. Either when the company was created from scratch or when it was a family takeover, the small business managers had to invest most of their savings into the company, and this aspect only adds to their concerns. Yet, although all family members often play a decisive part in the business, they do not all have a status, and most of them get involved without pay to support the business.

The great majority of private contractors officially do not have employees. Only managers make money out of their activities, thus providing for the family unit. So wives do not always have a professional status within the company, even though they may be working there in a structural way. The French Chamber of Trades $^{17}$ stresses that it is hard to keep a record of all the spouses carrying out a task within microbusinesses because, even though it has been mandatory since 2008 to declare a spouse's activity in this line of business, actually it is hardly ever done. Entrepreneurs justify this violation of the rule by saying it allows them to strengthen the company with some extra labour, without introducing in their already limited accounts the wages of an employee and their related costs. This is why it is hard to grasp the organisation of microbusinesses in a strictly capitalist logic given the numerous familial channels they are built on, which are at once their strength and their weakness.

\section{c. Heir and creator: two different approaches to the business}

The analysis of the first interviews points to a bi-polarised typology that should be clarified before further discussion. Although this typology calls for a more thorough examination in the final research study, it already brings to light divergences regarding the links between family and business. Two groups stand out: the heirs to family businesses and the entrepreneurs. Even though business takeovers within the family circle are clearly multidimensional and do not simply come down to a mere material transmission through the company, we will focus only on the takeover, by one member of the family, of the company that was created by one of his or her ancestors. This way, a handover of power can happen over generations, to the extent of creating a dynasty of businessmen, over at least three generations. Please note that out of the 20 people interviewed, 7 were handed over a family business. Among those 7 people, 6 were links in the chain of a dynasty of entrepreneurs. Nevertheless, the heir category may be divided into two distinct subgroups. On the one hand, those who follow in their ancestors' footsteps and carry on with the work organisation in an almost mimetic way, and on the other hand, those who completely rebuild the company. For the latter, who have reshaped the firm

\footnotetext{
16 The expression was mentioned several times in the course of the interviews with company managers and their spouses.

17 The Chambre des Métiers et de l'Artisanat is a state institution which references, manages and guides craftspersons through the creation/takeover and continued existence of their businesses.
} 
which had been handed over to them, the takeover allowed them to distinguish themselves from their predecessors. Either when it is about adding a chocolate branch to a bakery or making the move to organic farming, the discourse becomes hybrid. Admittedly, the interviewed people distance themselves from their ancestors through their groundbreaking idea or the innovation they have brought to the firm, but they also reify the family unit at work because they feel that they have been entrusted with their family's memory and legacy, which they carry through the business. Thus, whether they choose to carry on or to reshape the firm, the heirs take on a discourse in which their responsibility towards the company and the family memory is palpable, as if they felt indebted to their legacy.

As for business creators, one may think that they pass on the usual self-made-man professional rhetoric and constitute a homogeneous category, but this is not the case. In fact, an intermediate model emerges, through those who are nonetheless in line with the legacy. It is notably the case of 4 managers out of the 13 we interviewed. Take for instance Romain, who bought the company he had worked in for several years. Still a novice successor, he plans to reproduce this takeover pattern when he retires. As for the others, just like Romain, they wish to pass on the company to another novice successor, outside the family unit. It is for instance the case for Forest Worker Entrepreneurs, mainly because of the mothers' deterrent part in the transmission to their children (Shepens, 2004). This abnegation forces them to train an apprentice who may take over the business later on. It creates an adoptive filiation, in which the relationship between both players is similar to family ties. "The master-student relationship is also based on a "connection of souls" between two people; it also puts forward a chosen kinship and, by a genealogical accession mechanism which goes beyond the two contemporaries, it becomes a link in the "chain of generations"'" (Wacquet, 2008, p.17).

For the other creators, getting involved in entrepreneurship is more a matter of professional independence than a quest for durability. They appreciate the ephemeral nature of their business, which will run its course when they choose to retire. It is particularly relevant for the entrepreneurs who have launched a business to create their own job after a period of inactivity or a dismissal.

We have tried here to encapsulate the various components of the emerging typology of our empiric data so as to emphasize its heuristic aim in the rest of the article.

\section{d. A confusion of spaces for a junction of times}

Self-employed workers often have housing arrangements with several generations living under the same roof, above or next to the family business. This configuration of the links between family and business can lead at once to a familial and professional use of the property. The combined use of spaces is most frequent when the company was inherited. This proximity of private and professional spaces makes it possible to adapt the work rhythm to the flow of orders. Thus in the collected interviews, the firm is often inside or adjoining the family residence. The panel of heirs we met all had a residential configuration combining the home and the workplace. However, a disjunction between times and professional and familial spaces may be established as a principle, but it seems that this separation is put forth more strongly by the business creators previously mentioned. Actually, among the entrepreneurs, we noticed five residential situations where the accommodation is or was detached from the workplace, while absolutely all the heirs experienced a confusion of these spaces. For the heirs, this intermingling of private and professional spaces is rather a matter of family habit. Questioning this spatial organisation would imply a reassessment of the whole familial and professional organisation of the firm. As for business creators, they explain the separation of spaces as a will to keep business and family completely separated, while, as we will see later on, the members of the family unit are never far away from the business, even when creators are concerned.

\section{e. Providing family members with a professional status}

As I pointed out before, working together as a family in a microbusiness is a way to cope with economic and organisational difficulties. However, the typology presented above shows that family business inheritors tend to work more with their family circle. Five heirs out of seven 
involve their next of kin in the direct activity of the company. Both persons who do not work in a structural way with members of their families admit that they receive help occasionally from their parents, children or indirect relatives. As for the interviewed people who have created their firms, they advocate a separation between the business and the family spheres. Eight creators out of thirteen work with family members but, as we will see later on, they favour a professional status for their relatives, more than heirs do. In any case, the entrepreneurs' discourse tends to promote a bigger compartmentalisation between what's private and what's professional.

There is a noticeable difference in the protection of the relatives working for the family business, especially regarding the granting of a professional status. This status allows them to get wages and/or social welfare. Only two business creators have their wives working on a regular basis for the company without a professional status. But only three heirs out of the five who work together as a family have reported their spouses' jobs. Out of these three cases, two work as part of an Agricultural Association for Common Farming, which has been available to couples in France since the Agriculture and Fisheries Modernisation Act of July 27, 2010. This legal status of the business actually involves a status for both parties, in this case both spouses. Thus, although some business creators work with their relatives without a professional status, they seem more inclined to grant a status to the family members who actually work on a regular basis for the business, whereas it does not seem to be self-evident for the managers who have inherited a familial and professional form of organisation.

Arising out of these observations, the first typology induces a distinction in the very idea of a business and its connection with the family. Yet the issue of the interlocking of private and professional lives seems to be relevant even for those who have chosen to draw an impenetrable frontier between both worlds. The number of interviews conducted until now encourages us to venture the hypothesis that the distance between private or public, familial or professional times and spaces may vary according to the habits pertaining to the history of the business - whether it be familial, for the heirs, or not, for business creators.

\section{f. The legal status of the business as a detachment indicator?}

The intertwining of business and family in the case of microbusinesses is also different depending on the players' awareness of the legal and organisational issues crystallised around the business. Besides the professional status of family members working for the company, it also translates into the legal status of the business itself. In our sample group, the different legal statuses are centred around the limited liability company (Ltd, or SARL in French, for Société à responsabilité limitée) and the sole proprietorship (or El, for Entreprise Individuelle) statuses. Both statuses are characterised by the fact that they protect private property should the business go bankrupt. In the case of sole proprietorship, business assets and private property are interdependent, unless the people have signed a statutory declaration of nonseizability for their property, in the presence of a solicitor. It is not the case for the limited liability company status, which is a way for entrepreneurs to protect their families since the business is recorded as a legal entity, and professional assets and private property are therefore clearly separated.

This is precisely why more entrepreneurs choose the later legal status, which concerns half of our sample of entrepreneurs. Conversely, no business heir in our study has opted for business as a corporate body, in spite of their businesses being significantly bigger. Once again in a protectionist approach, the entrepreneurs' professional rhetoric expresses a will to separate family and business spheres while, paradoxically, the work is often done by members of the family unit.

\section{Conclusion}

The objective of this article was to highlight the first analytical threads of the ongoing Interreg research study. To make explicit our typology is interesting because it will enable us to reveal that the enterprise understanding between, heirs and creators, influences the way to protect the business and the family. That is why the protection degrees of enterprise and family circle lead to different consequences in the event of disruption. Therefore I chose to define precisely 
the current corpus of the study and its field of application through a relatively descriptive approach. The definition of the various elements correlative to the research study was a prerequisite to understand the project. We showed how family ties are likely to shape connections at work. Given the role of the couple when starting a business, and that of the spouse - and other members of the family unit - in the durability and stability of the business, it appears that one cannot really understand how microbusinesses work without taking into account the familial organisation and logics which underlie them. However, by means of the heir/creator typology described above, we can say that the ties between family and business do not have the same characteristics, not the same practical stakes for these two categories of managers. While all the people we met only had limited funds, company managers resort to strategies to overcome economic difficulties. These strategies often reflect gendered representations which are typical within our society. From the occasional unpaid assistance of the family - especially the spouse - to the total lack of professional status for family members, microbusinesses base their activity and stability on familial solidarities that do not appear on official statistics. The present typology brings to light differences as to the protection of the family and/or the work tool which is mostly related to the professional status granted to family members working for the company, to the legal form of the business itself, and to the confusion of spaces and times as far as work and domestic life is concerned. Indeed business creators try to separate the family unit from the business by setting up the measures described above. Their self-made-man rhetoric entails a vision of themselves as company managers with employees, even though in most cases their "employee" is actually their spouse. This strategy to separate private and business spheres shows that they wish to adopt a capitalistic representation of business while basing it on family ties. Such a separation/collaboration pattern questions the granting of a heritage status to the business. Thus we are faced with growing contradictions between the ideal type of the capitalist business and that of the family business. But analysing intergenerational transmission necessarily involves considering long periods of time, which was not possible until now. Therefore the selfmade-man rhetoric does not inevitably involve a lack of effective transmission of the business. Thus, as a conclusion, it seems relevant to recall that "the anthropological dimension of business takeovers, through the building of a professional filiation, whether those businesses are patrimonial or not, is always present and presides over the choice of a successor; it founds homo memor (the man who remembers)." (Jacques-Jouvenot, Schepens, 2007, p. 388).

\section{Acknowledgements}

I would like to sincerely thank the organizations that finance the Interreg IV-A program, which aims at promoting cooperation among European regions, especially in the field of urban, rural, economic and environmental development. I also thank all the colleagues who have contributed to build this collective research. Further thanks go to the hosts of the $4^{\text {th }}$ Moravian Conference on Rural Research, who allowed me to come and present our research and to submit this article.

References

[1] BAUER, M. (1991). De I'homo oeconomicus au pater familias. Le patron d'entreprise entre le travail, la famille et le marché (pp. 23-42). In Segalen, M., ed., Jeux de famille. Paris: Presses du CNRS.

[2] BERTAUX-WIAME, I. (2004). Devenir indépendant, une affaire de couple. Cahiers du genre, 37, 13-40.

[3] DAUMAS, J-C. (2010). Dictionnaire historique des patrons français. Paris: Flammarion.

[4] DAUMAS, J-C. (2012). La Franche-Comté, une histoire de spécialisation industrielle et de culture technique. Histoire d'entreprises, 10, 26-35.

[5] GOTMAN, A. (1988). Hériter. Paris: Presses Universitaires de France. 
[6] GRESLE, F. (1978). Indépendants et petits patrons. Pérennité et transformations d'une classe sociale [theses]. Paris: Université René Descartes.

[7] GRESLE, F. (1981). L'univers de la boutique. Les petits patrons du Nord (1920-1975). Lille: PUL/Septentrion.

[8] JACQUES-JOUVENOT, D. \& SCHEPENS, F. (2007). Transmettre ou reprendre une entreprise: de l'homo oeconomicus à I'homo memor. Revue du MAUSS 29, 377-391.

[9] JACQUES-JOUVENOT, D. (1997). Choix du successeur et transmission patrimoniale. Paris: L'Harmattan.

[10] KYORA, S. (2003a). Beherzte Pionierin. Cash Enterprise, 13 Juin 2003.

[11] KYORA, S. (2003b). Frauen warten nicht auf bessere Zeiten. Cash Enterprise, 13 Juin 2003.

[12] MAUSS, M. (1950). Sociologie et anthropologie. Paris, Presses Universitaires de France.

[13] MOINE, A. (2003). Evolution d'un espace transfrontalier: le territoire horloger franco-suisse de l'arc jurassien. L'information géographique 67, 21-34.

[14] PERRIER-CORNET, P., ed. (2002). Repenser les campagnes, Paris: Ed. de l'Aube.

[15] PINÇON, M. \& PINÇON-CHARLOT, M. (2006). Grandes fortunes: dynasties familiales et forme de richesse en France. Paris: Payot.

[16] SAINSAULIEU, R. (1990). L'entreprise, une affaire de société. Paris, Presses de la Fondation Nationale des Sciences Politiques.

[17] SCHEPENS, F. (2004). L'entrepreneur, sa femme et leurs enfants: de la recherche de l'indépendance à son dénigrement. Les cahiers du genre 37, 155-169.

[18] WACQUET, F. (2008). Les enfants de Socrate. Filiation intellectuelle et transmission du savoir XVIIe-XXIe siècle. Paris: Albin Michel.

[19] ZALIO, P-P. (1999). Grandes familles de Marseille au XXe siècle: enquête sur l'identité économique d'un territoire portuaire. Paris, Belin.

[20] ZARCA, B. (1986). L'artisanat français: du métier traditionnel au groupe social. Paris: Economica. 